\title{
GAS6 wt Allele
}

National Cancer Institute

\section{Source}

National Cancer Institute. GAS6 wt Allele. NCI Thesaurus. Code C101630.

Human GAS6 wild-type allele is located in the vicinity of $13 q 34$ and is approximately $44 \mathrm{~kb}$ in length. This allele, which encodes growth arrest-specific protein 6 , plays a role in both ligand-mediated signaling and receptor tyrosine kinase binding. 